\title{
PROBLEMATIKA YURIDIS PENJATUHAN SANKSI PIDANA MATI TERHADAP KORUPTOR PADA MASA PANDEMI COVID-19
}

\author{
Wildan Tantowi \\ Magister Ilmu Hukum Universitas Sebelas Maret, 57126, Surakarta \\ E-mail: wildantantowi@gmail.com
}

\begin{abstract}
Corrutiption is categorized as an extraordinary crime, the eradicting must also be done seriously. This article examines the criminal law policy of imposing the death penalty for corruptors during the covid-19 Pandemic. The Covid Pandemic in Indonesia as a national non-natural disaster which has been a serious concern of the government. In the event of corruption cases occur during the Covid-19 Pandemic, such criminal cases should be tackled in an extraordinary and special way because the impact of Covid-19 Pandemic has affected all sectors of life. Considering the Covid-19 Pandemic, it is appropriate if Indonesia is currently categorized under certain conditions. It means that this condition implies that if a criminal act of corruption occurs during the Covid-19 Pandemic, law enforcers can prosecute or impose a death penalty for corruption perpetrators as stipulated in Article 2 paragraph (1) and (2) of the Corruption Eradication Law. This research used the normative legal method which is carried out through literature study and used the statue approach to find out what weaknesses can lead to juridical problems with the enforcement of the death penalty against corruptors in Indonesia and to analyze the urgency of criminal law policy $n$ the imposition of the death penalty for corruptors during the Covid-19 Pandemic.
\end{abstract}

Keywords: Corruption Criminal Act, Death Penalty Imposition, Covid-19 Pandemic

\begin{abstract}
Abstrak
Tindak pidana korupsi dikategorikan sebagai extraordinary crime, Pemberantasan tindak pidana korupsi juga harus dilakukan dengan cara yang luar biasa. Artikel ini mengkaji tentang kebijakan hukum pidana penjatuhan sanksi pidana mati terhadap koruptor pada masa Pandemi Covid-19 . Pandemi Covid-19 di Indonesia ditetapkan sebagai bencana non-alam nasional yang telah menjadi perhatian serius dari pemerintah. Apabila terjadi tindak pidana korupsi pada masa Pandemi Covid-19 ini, maka penanggulangan tindak pidana korupsi tersebut harus dilakukan secara luar biasa dan khusus. Mengingat dampak dari Pandemi Covid-19 ini telah mempengaruhi segalam macam sektor kehidupan. Melihat kondisi Pandemi Covid-19 sudah selayaknya apabila Indonesia saat ini dikategorikan dalam kondisi keadaan tertentu. Artinya dari kondisi tersebut berimplikasi apabila terjadi tindak pidana korupsi pada masa Pandemi Covid-19 penegak hukum dapat menuntut atau menjatuhkan pidana mati bagi pelaku korupsi sebagaimana telah diatur dalam Pasal 2 ayat (1) dan (2) Undang-Undang Pemberantasan Tindak Pidana Korupsi. Metode Penelitian yang digunakan dalam artikel ini menggunakan metode penelitian hukum normatif yang dilakukan melalui studi kepustakaan dan dipadukan dengan pendekatan perundang-undangan yang nantinya tujuan dari penulisan artikel untuk mengetahui kelemahan-kelemahan apa saja yang dapat memunculkan sebuah problematika yuridis terhadap penegakan hukuman pidana mati kepada koruptor di Indonesia dan menganalisis urgensi kebijakan hukum pidana di Indonesia dalam penjatuhan pidana mati kepada koruptor pada masa Pandemi Covid-19.
\end{abstract}

Kata Kunci : Tindak Pidana Korupsi, Penjatuhan Pidana Mati, Pandemi Covid-19 


\section{A. Pendahuluan}

Salah satu perwujudan politik hukum nasional adalah penegakan hukum pidana yang menjadi sebuah keniscayaan yang harus diwujudkan dalam konstruksi pelaksanaan kebijakan hukum pidana ${ }^{1}$. Kebijakan hukum pidana merupakan sebuah mekanisme yang menjamin aturan-aturan yang ada dapat berlaku secara adil dan tegas dengan didukung oleh Aparat Penegak Hukum yang berintegritas menjadi sebuah konsep nyata dalam upaya penegakan hukum.

Tindak pidana korupsi telah menjadi sebuah kejahatan yang terstruktur sistematis dan meluas dalam ruang lingkup kehidupan, sehingga menjadikan korupsi sebagai kejahatan luar biasa (extraordinary crime). Selain merugikan negara secara ekonomi dan keuangan, hak-hak sosial dari masyarakat juga turut terdampak dari adanya praktik korupsi. Sebagi sebuah extarodinary crime penanggulangan dari tindak pidana korupsi juga harus dilakukan dengan strategi dan langkah yang luar biasa.

Undang-Undang Nomor 31 Tahun 1999 yang diperbarui dalam Undang-Undang Nomor 20 Tahun 2001 tentang Pemberantasan Tindak Pidana Korupsi (UU Tipikor) telah merumuskan sebuah formulasi penjeraan terhadap koruptor. Salah satu efek penjeraan yang dapat diberikan kepada para koruptor di Indonesia adalah dengan adanya sanksi pidana mati ${ }^{2}$.

Isu korupsi yang sedang hangat pada masa Pandemi Covid-19 ini adalah kasus suap bantuan sosial Covid-19 yang menjerat mantan Mentri Sosial, Juliari Batubara yang sampai saat ini masih ditangani oleh Komisi Pemberantasan Korupsi (KPK). Diduga, Juliari Batubara menerima suap sebesar Rp 8,2 Miliar dari proyek pengadaan Bansos Covid-19 dalam bentuk paket sembako dari Kementerian Sosial Republik Indonesia. Ditaksir biaya pengadaan Bansos Covid-19 senilai Rp 5,9 Triliun dengan 272 kontrak untuk dilaksanakan dalam dua periode bantuan. Mantan Mentri Sosial, Juliari Batubara diduga oleh KPK menerima fee dari penunjukan rekanan dalam proyek Bantuan Sosial Covid-19³.

Kondisi Indonesia yang masih bergulat dengan Pandemi Covid-19 menjadikan Indonesia masuk dalam kondisi keadaan tertentu. Kondisi tertentu yang dimaksud disini adalah Indonesia sedang mengalami kondisi yang tidak seperti biasanya, ketika Pandemi Covid-19 dan pembatasan aktivitas masyarakat telah memberikan dampak yang sangat besar bagi sektor kesehatan dan juga sektor-sektor lain seperti ekonomi. Undang-Undang Nomor 31 Tahun 1999 yang diperbarui dalam Undang-Undang Nomor 20 Tahun 2001 tentang Pemberantasan Tindak Pidana Korupsi telah mengatur adanya sanksi pidana mati dapat dituntut atau dijatuhkan oleh Aparat Penegak Hukum kepada koruptor yang melakukan korupsi pada keadaan tertentu.

Namun, wacana dalam penanggulangan dan pemberantasan korupsi melalui penerapan sanksi pidana mati untuk kasus korupsi khususnya dalam kondisi Pandemi Covid-19 ini

1 Vivi Ariyanti, “Kebijakan Penegakan Hukum Dalam Sistem Peradilan Pidana Indonesia,” Jurnal Yuridis 6, no. 2 (2019): 33-54, hlm 33.

2 Prasetyo Budi W; Pujiyono; Endah Sri Astuti, "Problem Yuridis Penerapan Sanksi Pidana Mati Terhadap Tindak Pidana Korupsi Menurut Undang-Undang Nomor 31 Tahun 1999 Jo Undang-Undang Nomor 20 Tahun 2001," Diponegoro Law Journal 5, no. 4 (2016): 1-12, hlm 2.

3 Detik News, "Mensos Juliari Batubara Tersangka Suap Bansos, Ini Konstruksi Kasusnya,” 06 Desember 2020, https:// news.detik.com/berita/d-5283490/mensos-juliari-batubara-tersangka-suap-bansos-ini-konstruksi-kasusnya/1, diakses pada 09 Desember 2020. 
ditentang oleh Institute For Criminal Justice Reform (ICJR). Menurut ICJR selama ini penjatuhan pidana mati di Indonesia hanya dijadikan sebagai narasi populis yang membuat seolah-olah pemerintah bekerja secara tegas dalam menanggulangi korupsi tetapi pada faktanya penjatuhan pidana mati tidak akan menyelesaikan permasalahan kejahatan yang dihadapi ${ }^{4}$.

Selain itu ICJR memperkuat argumennya dengan data Indeks Prestasi Korupsi tahun 2019 yang menunjukkan bahwa negara seperti Denmark, Finlandia dan Selandia Baru mempunyai indeks prestasi yang tinggi, artinya negara tersebut efektif dalam upaya pemberantasan korupsi dan ketiga negara tersebut tidak menerapkan pidana mati sebagai pemidanaan dalam pemberantasan tindak pidana korupsi. Sedangkan Indonesia yang mempunyai ancaman pidana mati untuk koruptor berada di peringkat 85 . Sehingga menurut ICJR penjatuhan hukuman mati kepada koruptor yang merupakan sikap reaktif harus diperbarui dengan pola pembaruan sistem pengawasan pada sektor-sektor yang rawan untuk terjadi praktik korupsi ${ }^{5}$.

Metode penelitian yang digunakan dalam artikel ini menggunakan penelitian hukum normatif yang dilakukan melalui studi kepustakaan dan dipadukan dengan pendekatan perundang-undangan yang mengaitkan permasalahan sanksi pidana mati terhadap pelaku tindak pidana korupsi pada masa Pandemi Covid-19 dengan aturan-aturan yang terkait ${ }^{6}$. Artikel ini difokuskan untuk mengkaji problematika yuridis dari penjatuhan pidana mati terhadap koruptor di Indonesia dan urgensi kebijakan hukum pidana di Indonesia dalam penjatuhan pidana mati terhadap koruptor berdasarkan Undang-Undang Tipikor pada masa Pandemi Covid-19.

\section{B. Pembahasan}

\section{Problematika Yuridis Penjatuhan Pidana Mati terhadap Koruptor di Indonesia}

Tindak pidana korupsi sebagai kejahatan luar biasa yang dapat menghancurkan moral bangsa dan memberikan kerugian negara yang berimbas pada terhambatnya pembangunan dan merampas keadilan serta kesejahteraan bangsa Indonesia. Salah satu opsi pemidanaan dalam sistem hukum di Indonesia adalah sanksi pidana mati. Undang-Undang Tipikor telah memformulasi adanya sanksi pidana mati kepada koruptor dan secara filosofis penjatuhan sanksi pidana kepada koruptor sudah sesuai dengan nilai moral Pancasila. Sehingga adanya sanksi pidana mati bagi koruptor dapat diterapkan dalam dialektika kehidupan di Indonesia yang berdasarkan Pancasila untuk mewujudkan keadilan?

Jerat pidana mati bagi koruptor tercantum dalam Pasal 2 Ayat (1) dan (2) UndangUndang Tipikor, sebagai berikut :

“(1) Setiap orang yang secara melawan hukum melakukan perbuatan memperkaya diri sendiri atau orang lain atau suatu korporasi yang dapat merugikan keuangan

4 Institute For Criminal Justice Reform, "Hentikan Narasi Populis Pidana Mati Untuk Tindak Pidana Korupsi,” 06 Desember 2020, https://icjr.or.id/hentikan-narasi-populis-pidana-mati-untuk-tindak-pidana-korupsi/, diakses pada 13 Desember 2020.

5 Ibid.

6 Peter Mahmud Marzuki, Penelitian Hukum, Revisi (Jakarta: PT Kharisma Putra Utama, 2017), hlm 133.

7 Amirullah Amirullah, “Tindak Pidana Korupsi Dan Sanksi Pidana Mati Perspektif Keadilan Hukum,” Al-Daulah: Jurnal Hukum Dan Perundangan Islam 3, no. 2 (2013): 323-55, hlm 351. 
negara atau perekonomian negara, dipidana penjara dengan penjara seumur hidup atau pidana penjara paling singkat 4 (empat) tahun dan paling lama 20 (dua puluh) tahun dan denda paling sedikit Rp. 200.000.000,00 (dua ratus juta rupiah) dan paling banyak Rp. 1.000.000.000,00 (satu milyar rupiah).

(2) Dalam hal tindak pidana korupsi sebagaimana dimaksud dalam ayat (1) dilakukan dalam keadaan tertentu, pidana mati dapat dijatuhkan".

Namun, pada realitanya sampai saat belum pernah ada penjatuhan sanksi pidana mati di Indonesia. Hal ini sekaligus menjadi faktor menjadikan Indonesia sebagai wahana yang indah bagi para koruptor, karena ancaman pidana mati yang tercantum dalam UU Tipikor belum pernah di eksekusi dan pastinya pengaturan hukuman mati bagi koruptor menjadi terabaikan. Hal ini disebabkan dari perumusan pidana penjatuhan pidana mati bagi koruptor hanya terdapat di Pasal 2 ayat (2) Undang-Undang Tipikor dan syarat penjatuhannya pun sangat sulit untuk diterapkan ${ }^{8}$.

Fakta dari ancaman pidana mati yang tercantum dalam UU Tipikor sampai saat ini belum pernah diterapkan terhadap koruptor disebabkan karena masih terdapat problematika yuridis dari formulasi penjatuhan pidana mati yang masih mempunyai beberapa kelemahan. Pertama, kelemahan dalam sisi substansi hukum bahwa pidana mati hanya dapat diancamkan atau diterapkan terhadap tindak pidana korupsi yang memenuhi unsur memperkaya diri sendiri atau orang lain atau korporasi yang dilakukan saat keadaan tertentu. Hal ini menjadi kelemahan yang cukup vital ketika ditambah dalam UU Tipikor tidak dirumuskan mengenai batasan pengulangan (recidive) tindak pidana korupsi ${ }^{9}$.

Kelemahan substansi hukum yang terdapat pada Pasal 2 ayat (2) UndangUndang Tipikor yang merumuskan penjatuhan pidana mati dapat dijatuhkan kepada koruptor yang melakukan korupsi pada keadaan tertentu mempunyai kata "dapat" yang tercantum didalamnya. Sehingga akibat hukum dari adanya kata "dapat" tersebut menyebabkan penjatuhan pidana mati kepada koruptor yang melakukan korupsi pada keadaan tertentu memiliki sifat fakultatif yang artinya penjatuhan pidana mati terhadap koruptor belum tentu dapat dilakukan. Selain itu, kata "dapat" dalam pasal tersebut juga dapat dimaknai secara subjektif yang artinya dapat disalah artikan dalam rangka meringankan koruptor ${ }^{10}$.

Kedua, kelemahan dalam sisi struktur hukum. Hal ini mengacu dengan masih terjadinya silang kepentingan antar Aparat Penegak Hukum, kewenangan penyidikan dapat dilakukan oleh Komisi Pemberantasan Korupsi (KPK) dan Kepolisian. Kemudian, wewenang menuntut yang biasanya dilakukan oleh Kejaksaan dapat di overlaping oleh KPK. Tumpang tindih wewenang dan yurisdiksi antar lembaga Aparat Penegak Hukum ini dapat memunculkan masalah struktural yang berpotensi memunculkan adanya gesekan antar lembaga dan ketika hal itu terjadi, maka dapat berimbas terhadap vonis

8 Risva Fauzi Batubara, “Kebijakan Formulasi Pidana Mati Terhadap Pelaku Tindak Pidana Korupsi Di Indonesia," Law Reform 10, no. 1 (2014): 74-83, hlm 75.

9 Barda Nawawi Arief, “Kebijakan Reformulasi Ancaman Pidana Mati Tindak Pidana Korupsi Dalam Peraturan PerundangUndangan,” Jurnal Masalah-Masalah Hukum 42, no. 1 (2013): 23-33, hlm 32.

10 Herman Katimin, “Kerugian Keuangan Negara Atau Perekonomian Negara Dalam Menentukan Hukuman Mati Pada Tindak Pidana Korupsi," Jurnal SASI 26, no. 1 (2020): 39-51, hlm $46 .$. 
yang dijatuhkan kepada koruptor tidak maksimal, sehingga tidak menimbulkan efek jera bagi koruptor ${ }^{11}$.

Ketiga, kelemahan dalam sisi kultur hukum. Lagi-lagi masih terdapat perbedaan perspektif mengenai kebijakan pidana mati. Kelompok yang kontra terhadap pidana mati beranggapan jika penjatuhan pidana mati sama saja dengan pelanggaran Hak Asasi Manusia (HAM). Hak Asasi Manusia pada prinsipnya merupakan hak mutlak yang dimiliki oleh manusia sejak lahir sampai meninggal dunia tetapi dalam pelaksanaan hak tersebut disertai dengan pelaksanaan kewajiban dan tanggungjawab. Mengingat hak asasi manusia sudah sejak awal melekat pada diri manusia dan berasal dari Tuhan, maka hak asasi manusia tidak dapat untuk dikurangi atau bahkan dicabut. Oleh karena itu Indonesia sebagai negara hukum dituntut untuk memberikan perlindungan bagi hak asasi manusia ${ }^{12}$.

Ketiga problematika yuridis ini menjadi muara apakah penjatuhan pidana mati bagi koruptor di Indonesia layak untuk diterapkan?, kerana faktanya aturan hukum yang telah dirumuskan tidak berdaya dalam menanggulangi tindak pidana korupsi dengan adanya kata "dapat" dalam Pasal 2 ayat (2) UU Tipikor yang merekonstruksi dijatuhkannya pidana mati bagi koruptor. Selain itu, penafsiran kata "dapat" bersifat subjektif ditambah dengan perangkat hukum yang lemah dalam menanggulangi tindak pidana korupsi. Narasi penjatuhan pidana mati bagi koruptor sering digaungkan akan tetapi tetap saja selalu ada pihak yang tidak setuju dengan arah kebijakan sanksi pidana mati karena melanggar Hak Asasi Manusia. Sehingga akan selalu ada polemik menganai kebijakan hukuman mati bagi koruptor ${ }^{13}$.

Menurut Institute For Criminal Justice Reform (ICJR) paradigma pemidanaan juga telah bergeser dari teori retributif (pembalasan) menuju arah teori restoratif. Ketika dikaitkan dengan kasus korupsi konsen utama dari teori restoratif ini adalah fokus kepada pengembalian kerugian negara dan mereformasi sistem pengawasan terhadap sektor-sektor yang rawan akan terjadinya tindak pidana korupsi. Penjatuhan pidana mati kepada koruptor juga bukan solusi dalam penanggulangan tindak pidana korupsi, karena fakta dalam indeks prestasi pemberantasan korupsi, negara yang menempati peringkat tertinggi dalam menangani korupsi tidak menerapkan hukuman mati ${ }^{14}$.

Selain itu, mitos dari pemberian efek jera dalam penjatuhan pidana mati juga belum dapat dibuktikan dalam penelitian ilmiah ${ }^{15}$. Sekali tiga uang dengan Indonesia, narasi penjatuhan pidana mati bagi koruptor hanya menjadi sebuah fenomena penal populism yang termanifestasi dalam pengambilan kebijakan hukum yang irrasional dengan mengeksploitasi kemarahan publik terhadap korupsi guna membangun sentimen punitif yang semata-mata digunakan untuk meraih reputasi dan simpati publik ${ }^{16}$.

11 Astuti, Opcit, hlm 7

12 Bagir Manan, Perkembangan Pemikiran Dan Pengaturan Hak Asasi Manusia Di Indonesia (Jakarta: Yayasan Hak Asasi Manusia, Demokrasi dan Supremasi Hukum, 2001), hlm 14.

13 Surahmad, “Kontroversi Kebijakan Hukuman Mati Bagi Koruptor Di Indonesia," Pusdiknas : Jurnal Ilmiah Kebijakan Nasional Dan Internasional 2, no. 3 (2016): 23-30, hlm 29.

14 Iftitahsari, "Hukuman Mati Dalam Pemberantasan Korupsi”, Bahan Seminar disampaikan pada Weinar Jurist Wanna Be : Haruskah Hukuman Mati Bagi Koruptor?, Zoom Meeting, 12 Desember 2020, hlm 1-2.

15 Berit Gerritzen and Gebhard Kirchgässner, "Facts or Ideology: What Determines the Results of Econometric Estimates of the Deterrent Effect of the Death Penalty? A Meta-Analysis," Open Journal of Social Sciences 04, no. 06 (2016): 178-202, hlm 202

16 Iftitahsari, Op.cit, hlm 6. 
Selain terdapat pihak yang kontra terhadap hukuman mati, terdapat juga pihak yang pro dengan hukuman mati. Hal ini didasari dengan alasan awal bahwa akibat yang ditimbulkan dari korupsi sangatlah luas, sehingga penjatuhan sanksi seberat-beratnya patut untuk diberikan dan setiap unsur kesalahan atau tindak pidana terkandung dalam sebuah perbuatan harus dapat dipertanggungjawabkan sesuai dengan aturan hukum yang berlaku sebagaimana dikenal dalam asas pokok pertanggungjawaban pidana yaitu asas tiada pidana tanpa kesalahan ${ }^{17}$.

Melihat dampak yang ditimbulkan dari korupsi yang mengakibatkan kehancuran yang luar biasa bagi kehidupan bangsa. Tidak hanya hancur dari sisi ekonomi saja tetapi sisi moralitas bangsa juga turut mengalami degradasi dari tindak pidana korupsi yang seolah telah menjadi 'budaya' yang mengakar dari bangsa ini. Efek yang ditimbulkan akan semakin berkelanjutan dan posisi bangsa Indonesa makin rendah di mata dunia internasional apabila tidak mampu mengendalikan korupsi. Sehingga penjatuhan sanksi pidana mati bagi koruptor tetap pantas untuk diterapkan ${ }^{18}$.

Stabilitas keamanan masyarakat serta telah dilanggarnya nilai demokrasi, etika dan keadilan yang secara komprehensif dapat membahayakan pembangunan, tidak heran jika korupsi dikategorikan sebagai persoalan yang serius berdasarkan United Nations Corruption Againts Convention (UNCAC). Ditambah dengan dukungan Pasal 6 ayat (2) Internasional Convenant on Civil and Political Rights (ICCPR) yang menyatakan bahwa penjatuhan pidana mati pada jenis kejahatan yang serius masih dapat untuk diterapkan. Berdasarkan ketentuan tersebut, pidana mati tidak bertentangan dengan ketentuan internasional ${ }^{19}$.

\section{Urgensi Kebijakan Hukum Pidana di Indonesia dalam Penjatuhan Pidana Mati bagi Koruptor Berdasarkan Undang-Undang Tipikor pada Masa Pandemi Covid-19}

Menurut Busyro Muqodas terdapat tiga kriteria utama yang dapat dijadikan dasar koruptor dapat dijatuhi hukum mati. Pertama, kerugian yang dialami negara ditaksir lebih dari 100 miliar dan secara masif menimbulkan kerugian bagi rakyat. Kedua, pejabat negara yang menjadi pelaku korupsi dan ketiga, pelaku korupsi yang melakukan korupsi berulang-ulang ${ }^{20}$.

Ujung tombak peraturan perundang-undangan yang mengandung upaya penanggulangan tindak pidana korupsi telah terformulasi secara khusus dalam UndangUndang Nomor 31 Tahun 1999 yang diperbarui dalam Undang-Undang Nomor 20 Tahun 2001 tentang Pemberantasan Tindak Pidana Korupsi ${ }^{21}$. Salah satu kelemahan

17 Oksidelfa Yanto, "Penjatuhan Pidana Mati Pelaku Tindak Pidana Korupsi Dalam Keadaan Tertentu," Jurnal Legislasi Indonesia 14, no. 1 (2017): 49-56, hlm 52.

18 Anshari dan Muhammad Fajrin, "Urgensi Ancaman Hukuman Pidana Mati Pada Pelaku Tindak Pidana Korupsi (Analisis Yuridis Normatif Terhadap Kebijakan Hukum Pidana/Penal Policy Sanksi Pidana Mati Di Indonesia),” Res Judicata 3, no. 1 (2020): 26-50, hlm 45.

19 Warih Anjari, “Penerapan Pidana Mati Terhadap Terpidana Kasus Korupsi," Jurnal Masalah-Masalah Hukum 49, no. 4 (2020): 432-442, hlm 440-441.

20 Elsa R M Toule, “Eksistensi Ancaman Pidana Mati Dalam Undang-Undang Tindak Pidana,” Jurnal Hukum Prioris 3, no. 3 (2013): 103-110, hlm 106 .

21 Fitriati, “Analisis Perkembangan Sistem Peradilan Pidana Ditinjau Dari Perspektif Pengadilan Tindak Pidana Korupsi," Jurnal Yustisia 90, no. 31 (2014): 73-82, hlm 74. 
dalam upaya pemberantasan korupsi terletak pada sanksi yang tidak menimbulkan efek jera bagi koruptor. Masih banyak perangkat hukum yang lemah dan malah memberikan sebuah realitas yang ironi kepada masyarakat ketika koruptor malah diberikan sebuah privilege menjadikan sebuah cerminan yang nyata bahwa perangkat hukum tidak bermuara pada keadilan dan perlindungan masyarakat ${ }^{22}$.

Eksistensi pidana mati di Indonesia telah disikapi oleh Mahkamah Konstitusi bahwa sanksi pidana mati tetap dipertahankan sebagai salah satu opsi pemidanaan untuk kejahatan-kejahatan tertentu. Hal ini didasari bahwa hak hidup seseorang tidak dilanggar oleh hukuman mati yang dijatuhkan kepadanya. ICCPR menyebutkan pidana mati dapat diterapkan pada kejahatan yang bersifat serius, selain itu penafisran oleh MK tentang hak asasi manusia harus digunakan untuk menghargai hak asasi manusia orang lain untuk mencapai sebuah ketertiban umum dan keadilan sosial juga telah terkonstruksi dalam Undang-Undang Nomor 39 Tahun 2009 tentang HAM ${ }^{23}$.

Pandemi Covid-19 yang sedang berlangsung sampai saat ini masuk sebagai bencana non-alam yeng bersifat bencana nasional telah ditetapkan dalam Keputusan Presiden Nomor 12 Tahun 2020 tentang Penyebaran Corona Virus Disease 2019 (Covid 19). Adanya Pandemi Covid-19 ini telah memberikan dampak yang luas dalam kehidupan masyarakat, Pemutusan Hubungan Kerja (PHK) naik signifikan, dirumahkan, pembatasan aktivitas membuat mobilitas perusahaan terganggu, ranah UMKM jatuh bahkan banyak yang sudah tidak dapat beroperasi lagi. Melihat Pandemi Covid-19 telah menimbulkan dampak yang luas. Wajar ketika Pandemi Covid-19 ini dapat menjadi faktor kriminogen seseorang untuk melakukan kejahatan ${ }^{24}$.

Kasus suap Bantuan Sosial Kementerian Sosial RI yang menjerat mantan Mentri Juliari Batubara menjadi bukti nyata bahwa Pandemi Covid-19 dapat memunculkan kesempatan untuk melakukan kejahatan dalam kasus ini adalah tindak pidana korupsi. Selain itu dari kasus ini juga memberikan bukti nyata bahwa program pemerintah yang seharusnya digunakan untuk memberikan stimulus bagi masyarakat untuk bertahan di masa Pandemi ini, malah menjadi ladang korupsi pejabat tinggi terkait. Jerat pidana mati terhadap koruptor telah diatur dalam Pasal 2 ayat (1) dan (2) UU Tipikor. Namun, dalam praktik sejarah penegakan hukum di Indonesia ketika menindak kasus korupsi sampai saat ini penjatuhan pidana mati bagi koruptor belum pernah sama sekali terjadi. Hal ini didasari dengan hanya terdapat satu pasal dalam UU Tipikor yang memformulasi penjatuhan pidana mati bagi koruptor, sehingga menunjukkan bahwa substansi hukum dalam penanggulangan korupsi melalui UU Tipikor juga masih lemah. UU Tipikor yang mengatur penjatuhan pidana mati juga masih menimbulkan multitafsir karena terdapat frasa keadaan tertentu yang terdapat dalam Pasal 2 ayat (2) UU Tipikor ${ }^{25}$

Penjelasan dari Pasal 2 ayat (2) UU Tipikor yang menjadi syarat penjatuhan hukuman pidana mati bagi koruptor apabila melakukan korupsi pada "keadaan tertentu" dirumuskan sebagai berikut :

22 Evi Hartanti, Tindak Pidana Korupsi, Kedua (Jakarta: Sinar Grafika, 2009), hlm 3.

23 Yan David Bonitua, Pujiyono, and Purwoto, "Sikap Dan Pandangan Mahkamah Konstitusi Terhadap Eksistensi Sanksi Pidana Mati Di Indonesia,” Diponegoro Law Journal 6, no. 1 (2017): 1-18, hlm 14.

24 Rofiq Hidayat, "Potret Penegakan Hukum Kala Pandemi Covid-19," 22 Mei 2020, https://www.hukumonline.com/berita/ baca/1t5ec7411c5efdc/potret-penegakan-hukum-kala-Pandemi-covid-19, diakses pada 10 Desember 2020.

25 Astuti, OpCit, hlm 7. 
“Yang dimaksud dengan keadaan dengan 'keadaan tertentu' dalam ketentuan ini dimaksudkan sebagai pemberatan bagi pelaku tindak pidana korupsi apabila tindak pidana tersebut dilakukan pada waktu negara dalam keadaan bahaya sesuai dengan undang-undang yang berlaku, pada waktu terjadi bencana alam nasional, sebagai pengulangan tindak pidana korupsi, atau pada waktu negara dalam keadaan krisis ekonomi dan moneter"

Pandemi Covid-19 ditetapkan sebagai bencana non-alam yang bersifat bencana nasional. beberapa rangkaian peristiwa dan kebijakan (darurat kesehatan masyarakat dan darurat bencana non-alam) menjadikan Indonesia saat ini sedang berada dalam situasi bahaya dan tidak stabil karena Pandemi Covid-19 , hal ini jika ditelisik sesuai dalam Penjelasan Pasal 2 ayat (2) UU Tipikor tentang keadaan tertentu. Konsekuensi yuridis dari rangkaian peristiwa diatas adalah bahwa seseorang yang melakukan tindak korupsi sebagaimana memenuhi rumusan Pasal 2 UU Tipikor, maka penegak hukum dapat menuntut maupun menjatuhkan pidana mati terhadap terdakwa. Walaupun tindakan para koruptor dianggap sebagai suatu kesalahan yang harus dipertanggungjawabkan secara hukum, fakta tidak pernah dijatuhkannya eksekusi pidana mati menjadikan Indonesia sebagai komoditas baru bagi pelaku tindak pidana korupsi. Hingga saat ini hakim belum pernah menjatuhkan vonis pidana mati bagi pelanggar Pasal 2 UU Tipikor. Dengan demikian, sekarang merupakan saat yang tepat bagi para penegak hukum khususnya hakim dalam menerapkan pidana mati terhadap koruptor yang melakukan korupsi pada masa Pandemi Covid-1926

\section{Kesimpulan}

Berdasarkan pembahasan atas permasalahan yang telah dikaji, maka dalam artikel ini dapat diambil kesimpulan sebagai berikut :

1. Problematika yuridis penjatuhan pidana mati terhadap koruptor di Indonesia terletak pada berjalannya sistem hukum di Indonesia yang masih terdapat kelemahan substansi hukum, struktur hukum dan budaya hukum dalam upaya pemberantasan tindak pidana korupsi.

2. Urgensi dari kebijakan hukum pidana di Indonesia dalam penjatuhan pidana mati kepada koruptor pada masa Pandemi Covid-19 harus diberikan perhatian serius, karena Pandemi Covid-19 telah memberikan dampak yang luas bagi semua lini kehidupan, sehingga apabila terjadi korupsi pada masa Pandemi ini, maka dapat memberikan konsekuensi yuridis bahwa pelaku koruptor pada masa Pandemi Covid-19 dapat dituntut atau dijatuhi pidana mati.

\section{Daftar Pustaka}

Amirullah, Amirullah. "Tindak Pidana Korupsi Dan Sanksi Pidana Mati Perspektif Keadilan Hukum." Al-Daulah: Jurnal Hukum Dan Perundangan Islam 3, no. 2 (2013): 323-55. https://doi.org/10.15642/ad.2013.3.2.323-355.

26 Mohammad Khairul Muqorobin dan Barda Nawawi Arief, “Kebijakan Formulasi Pidana Mati Dalam Undang-Undang Pemberantasan Tindak Pidana Korupsi Pada Masa Pandemi Corona Virus Disease 2019 (COVID-19) Berdasarkan Perspektif Pembaharuan Hukum Pidana," Jurnal Pembangunan Hukum Indonesia 2, no. 3 (2020): 387-398, hlm 396. 
Anjari, Warih. "Penerapan Pidana Mati Terhadap Terpidana Kasus Korupsi.” Jurnal MasalahMasalah Hukum 49, no. 4 (2020): 432-42. https://doi.org/10.14710/mmh.49.4.2020.432442.

Anshari, and Muhammad Fajrin. "Urgensi Ancaman Hukuman Pidana Mati Pada Pelaku Tindak Pidana Korupsi (Analisis Yuridis Normatif Terhadap Kebijakan Hukum Pidana/ Penal Policy Sanksi Pidana Mati Di Indonesia).” Res Judicata 3, no. 1 (2020): 26-50.

Arief, Barda Nawawi. "Kebijakan Reformulasi Ancaman Pidana Mati Tindak Pidana Korupsi Dalam Peraturan Perundang-Undangan.” Jurnal Masalah-Masalah Hukum 42, no. 1 (2013): 23-33. https://doi.org/10.14710/mmh.42.1.2013.23-33.

Ariyanti, Vivi. "Kebijakan Penegakan Hukum Dalam Sistem Peradilan Pidana Indonesia." Jurnal Yuridis 6, no. 2 (2019): 33-54. https://doi.org/10.35586/jyur.v6i2.789.

Astuti, Prasetyo Budi W; Pujiyono; Endah Sri. "Problem Yuridis Penerapan Sanksi Pidana Mati Terhadap Tindak Pidana Korupsi Menurut Undang-Undang Nomor 31 Tahun 1999 Jo Undang-Undang Nomor 20 Tahun 2001.” Diponegoro Law Journal 5, no. 4 (2016): 1-12.

Batubara, Risva Fauzi. "Kebijakan Formulasi Pidana Mati Terhadap Pelaku Tindak Pidana Korupsi Di Indonesia.” Law Reform 10, no. 1 (2014): 74-83. https://doi.org/10.14710/ lr.v10i1.12458.

Bonitua, Yan David, Pujiyono, and Purwoto. "Sikap Dan Pandangan Mahkamah Konstitusi Terhadap Eksistensi Sanksi Pidana Mati Di Indonesia." Diponegoro Law Journal 6, no. 1 (2017): 1-18.

Detik News. "Mensos Juliari Batubara Tersangka Suap Bansos, Ini Konstruksi Kasusnya." www.news.detik.com, 2020. https://news.detik.com/berita/d-5283490/mensos-juliaribatubara-tersangka-suap-bansos-ini-konstruksi-kasusnya/1.

Fitriati. "Analisis Perkembangan Sistem Peradilan Pidana Ditinjau Dari Perspektif Pengadilan Tindak Pidana Korupsi.” Jurnal Yustisia 90, no. 31 (2014): 73-82.

Gerritzen, Berit, and Gebhard Kirchgässner. "Facts or Ideology: What Determines the Results of Econometric Estimates of the Deterrent Effect of the Death Penalty? A Meta-Analysis." Open Journal of Social Sciences 04, no. 06 (2016): 178-202. https://doi.org/10.4236/ jss.2016.46020.

Hartanti, Evi. Tindak Pidana Korupsi. Kedua. Jakarta: Sinar Grafika, 2009.

Hidayat, Rofiq. "Potret Penegakan Hukum Kala Pandemi Covid-19.” www.hukumonline.com, 2020. https://www.hukumonline.com/berita/baca/lt5ec7411c5efdc/potret-penegakanhukum-kala-Pandemi-covid-19.

Iftitahsari. "Hukuman Mati Dalam Pemberantasan Korupsi.” Jakarta, 2020.

Institute For Criminal Justice Reform. "Hentikan Narasi Populis Pidana Mati Untuk Tindak Pidana Korupsi.” https://icjr.or.id, 2020. https://icjr.or.id/hentikan-narasi-populis-pidanamati-untuk-tindak-pidana-korupsi/. 
Katimin, Herman. "Kerugian Keuangan Negara Atau Perekonomian Negara Dalam Menentukan Hukuman Mati Pada Tindak Pidana Korupsi.” Jurnal SASI 26, no. 1 (2020): 39-51. https://doi.org/10.47268/sasi.v26i1.210.

Manan, Bagir. Perkembangan Pemikiran Dan Pengaturan Hak Asasi Manusia Di Indonesia. Jakarta: Yayasan Hak Asasi Manusia, Demokrasi dan Supremasi Hukum, 2001.

Marzuki, Peter Mahmud. Penelitian Hukum. Revisi. Jakarta: PT Kharisma Putra Utama, 2017.

Muqorobin, Mohammad Khairul, and Barda Nawawi Arief. “Kebijakan Formulasi Pidana Mati Dalam Undang-Undang Pemberantasan Tindak Pidana Korupsi Pada Masa Pandemi Corona Virus Disease 2019 (COVID-19) Berdasarkan Perspektif Pembaharuan Hukum Pidana." Jurnal Pembangunan Hukum Indonesia 2, no. 3 (2020): 387-98. https://doi. org/10.14710/jphi.v2i3.387-398.

Surahmad. "Kontroversi Kebijakan Hukuman Mati Bagi Koruptor Di Indonesia." Pusdiknas : Jurnal Ilmiah Kebijakan Nasional Dan Internasional 2, no. 3 (2016): 23-30.

Toule, Elsa R M. “Eksistensi Ancaman Pidana Mati Dalam Undang-Undang Tindak Pidana.” Jurnal Hukum Prioris 3, no. 3 (2013): 103-10.

Yanto, Oksidelfa. "Penjatuhan Pidana Mati Pelaku Tindak Pidana Korupsi Dalam Keadaan Tertentu." Jurnal Legislasi Indonesia 14, no. 1 (2017): 49-56. http://e-jurnal.peraturan. go.id/index.php/jli/article/download/76/pdf. 